BENHA VETERINARY MEDICAL JOURNAL, VOL. 31, No. 1:24-29, SEPTEMBER, 2016

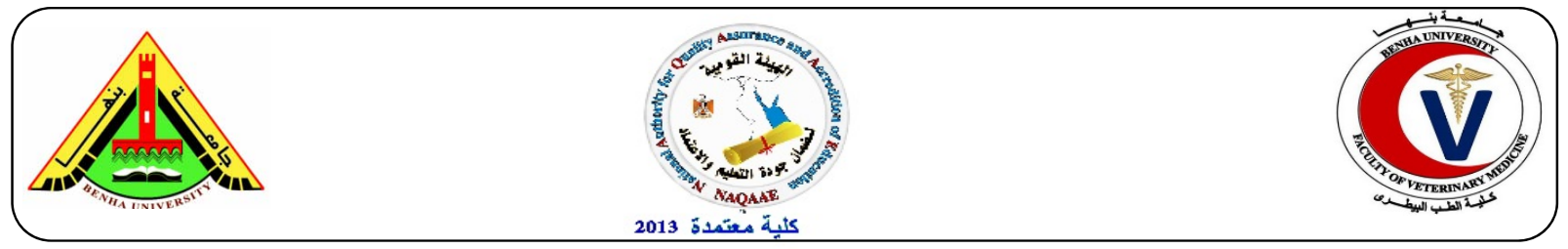

\title{
Bacteriological Evaluation of Some Fresh and Frozen fish
}

Ibrahim - Hemmat M. ${ }^{1}$; Reham A. Amin ${ }^{1}$, Shawkey Nahela ${ }^{2}$, A. and Mohammed- Hend. E.

1. Food control Dept., Fac. Vet. Med. ${ }^{2}$. Animal Research Institute Shebin El- Koom

\begin{abstract}
A B S T R A C T
Ninety random samples of fresh and frozen each of Tilapia niloticus, Mugil cephalus and Shrimp (15 of each) were collected from different fish markets at Qaliuobia Governorate. All collected samples were bacteriologically examined for determination of Aerobic Plate Count (APC), psychrotrophic count, Isolation and Identification of pseudomonas and Aeromonas species. The bacteriological examination revealed the mean values of APC in the examined fish samples was $1.52 \times 10^{6} \pm 0.47 \times 10^{6}$ and $3.08 \times 10^{5} \pm 1.31 \times 10^{5}$ in fresh and frozen Tilapia niloticus, $7.14 \times 10^{5} \pm 1.84 \times 10^{5}$ and $2.59 \times 10^{5} \pm$ $0.62 \times 10^{5}$ in fresh and frozen Mugil cephalus and $7.81 \times 10^{4} \pm 2.07 \times 10^{4}$ and $1.36 \times 10^{4} \pm 0.42 \times 10^{4} / \mathrm{g}$, in fresh and frozen shrimp. The mean values of psychrotrophic count in fresh and frozen Tilapia niloticus were $2.67 \times 10^{5} \pm 0.45 \times 10^{5}$ and $5.36 \times 10^{5} \pm 1.24 \times 10^{5} \mathrm{cfu} / \mathrm{g}$, respectively. $4.91 \times 10^{4} \pm 0.93 \times 10^{5}$ and $1.72 \times 10^{5} \pm 0.46 \times 10^{5} / \mathrm{gm}$ respectively in fresh and frozen Mugil cephalus. $7.81 \times 10^{4} \pm 2.07 \times 10^{4}$ and $6.51 \times 10^{4} \pm 1.80 \times 10^{4} / \mathrm{g}$, in fresh and frozen shrimp. The incidence of Pseudomonas species was $33.3 \%$ and $53.3 \%$ in the examined samples of fresh and frozen Tilapia niloticus, $46.7 \%$ and $60.0 \%$ in fresh and frozen Mugil cephalu, respectively, $33.3 \%$ and $40.0 \%$ in fresh and frozen shrimp, respectively. The incidence of Aeromonas species were $46.7 \%$ and $33.3 \%$ in the examined samples of fresh and frozen Tilapia niloticus, $53.3 \%$ and $40.0 \%$ in fresh and frozen Mugil cephalus, respectively, $33.3 \%$ and $40.0 \%$ in fresh and frozen shrimp, respectively.
\end{abstract}

Key words: Fresh fish, Frozen fish, Tilapia niloticus, Mugil cephalus

(http://www.bvmj.bu.edu.eg)

(BVMJ-31(1): 24-29, 2016)

\section{Introduction}

Fish is an important food with high nutritive value, scince it is a source of low price animal protein and other important nutrients such as calcium, phosphorus, and vitamins. Fresh fish is extremely perishable and the time elapsed post catch and the holding temperature significantly affect the odor and flavor profile of the fish (Russell, 1998). Off odor and off flavor are produced when bacterial numbers reach $10^{7} \mathrm{cfu} / \mathrm{g}$ of fish (Jay, 2000). Bacterial contamination is either due to direct contamination of the fish by polluted water or due to secondary contamination during handling, processing, storage, distribution or preparation. Such contamination is of particular importance when fish is eaten raw or only lightly processed. The most bacterial species responsible for fish spoilage are Pseudomonas and Aeromonas (Lu and $\mathrm{Bi}, 2007)$. Aerobic plate count on fish generally do not relate to food safety hazards, but sometimes can be useful to indicate quality, shelf life and post heat processing contamination. Fresh fish and fishery products often have an APC of $10^{6}-10^{8}$ without objectionable quality changes (Nickelson and Finne, 1992). Psychrotrophs are these bacteria that grow well at or below $7^{\circ} \mathrm{C}$ and have their optimum temperature for growth between $20-30^{\circ} \mathrm{C}$. Some psychrotrophic pathogens can grow in the refrigerated food with little or no obvious change of sensory characteristics (Berrang et al., 1989). Pseudomonas species are important spoilage organisms in many chilled food products especially fish in which they become the dominant microflora during chill storage (Gram, 1993). In addition, their presence in fish create a great risk as they lead to poisoning and / or spoilage of fish (Jay, 2000). Aeromonas species play a major role in the spoilage of fresh fish and its products (Gram and Huss, 1996). Also, they are responsible for wide range spectrum of diseases among aquatic organisms and human (Ebanks et al., 2005) as motile Aeromonas Septicemia in fish which is caused by $A$. hydrophila leading to high mortalities and high economic losses (Dhanaraj et al., 2008). Therefore, the present work was planned out to determine the Aerobic Plate Count and Total psychrotrophic count of some Fresh and frozen fish (Tilapia niloticus, Mugil cephalus and Shrimp) and isolation and identification of pseudomonas and Aeromonas species. 


\section{MATERIAL AND METHODS}

\subsection{Collection of fish samples:}

A total of 90 random samples of fresh and frozen of each of Tilapia niloticus, Mugil cephalus and Shrimp (15 of each) were collected from different fish markets at Kaliobia Governorate. Each sample were kept individually in separate plastic bag and transferred directly to the laboratory in an insulated ice box under complete aseptic conditions without undue delay. All collected samples were examined bacteriologically as rapidly as possible.

\subsection{Preparation of samples (APHA, 1992.):}

Accurately, 25 grams of the examined fish flesh were transferred to a sterile polyethylene bag and $225 \mathrm{ml}$ of $0.1 \%$ sterile buffered peptone water were aseptically added to the content of the bag. Each sample was then homogenized in a blender at 2000 rpm for 1-2 minutes to provide a homogenate of $1 /$ '10 dilution from which ten fold serial dilutions were prepared.

\subsubsection{Aerobic plate count (FAO., 1992).}

One $\mathrm{ml}$ from each of the previously prepared serial dilutions was carefully transferred into each of the appropriately marked sterile petri-dishes, and thoroughly mixed with about $15 \mathrm{ml}$ of previously melted and cooled $\left(45 \pm 1^{\circ} \mathrm{C}\right)$ standard plate count agar. After solidification, the inoculated plates were inverted and incubated at $35^{\circ} \mathrm{C}$ for $48 \mathrm{hr}$.Plates with $25-250$ colonies were selected and counted.

\subsubsection{Determination of Psychotropic count (Collins and Lyne, 1984).}

One $\mathrm{ml}$ from each of the previously prepared serial dilutions, was transferred by using a sterile pipette into two separate sterile Petri-dishes to which approximately $15 \mathrm{ml}$ of sterile melted and tempered plate count agar $\left(45^{\circ} \mathrm{C}\right)$ were added and mixed. The inoculated plates were gently shaken in rotatory movement and left till complete solidification of the agar. The plates were inverted and incubated at $7^{\circ} \mathrm{C}$ for 10 days. The total Psychrotrophic count/g was calculated on plates containing 30-300 colonies.

\subsubsection{Isolation of Pseudomonas species (ICMSF., 1996): Pseudomonas Aeromonas agar medium.}

Identification of Pseudomonas species, (Krieg and Holt, 1984). Microscopical examination (A.P.H.A., 1992.). Biochemical identification: (Quinn et al., 2002). Isolation of Aeromonas species (ICMSF., 1996): Pseudomonas Aeromonas agar medium. Identification of Aeromonas species: Microscopical examination (A.P.H.A., 1992.). Biochemical identification: (Baron and Finegold, 1990).

\section{RESULTS}

Regarding the results recorded in table (1), it is obvious that the APC ( $\mathrm{cfu} / \mathrm{g}$ ) of each of fresh Tilapia niloticus, fresh Mugil cephalous, fresh shrimp, frozen Tilapia niloticus, frozen Mugil cephalous and frozen shrimp were $1.52 \times 10^{6} \pm$ $0.47 \times 10^{6}, \quad 7.14 \times 10^{5} \pm 1.84 \times 10^{5}, \quad 7.81 \times 10^{4} \pm$ $2.07 \times 10^{4}, \quad 3.08 \times 10^{5} \pm 1.31 \times 10^{5}, \quad 2.59 \times 10^{5} \pm$ $0.62 \times 10^{5}$ and $1.36 \times 10^{4} \pm 0.42 \times 10^{4}$ respectively. The psychrotrophic count/ $g$ of the examined samples of each of fresh Tilapia niloticus, fresh Mugil cephalous, fresh shrimp, frozen Tilapia niloticus, frozen Mugil cephalous and frozen shrimp recorded in table (2) were $2.67 \times 10^{5} \pm$ $0.45 \times 10^{5}, \quad 6.51 \times 10^{4} \pm 1.80 \times 10^{4}, \quad 2.88 \times 10^{4} \pm$ $0.59 \times 10^{4}, \quad 5.36 \times 10^{5} \pm 1.24 \times 10^{5}, \quad 1.72 \times 10^{5} \pm$ $0.46 \times 10^{5}$ and $4.91 \times 10^{4} \pm 0.93 \times 10^{5}$ respectively. Incidence of identified psychrotrophic bacteria isolated from the examined samples of fish was shown in table (3). Accurately, Acinetobacter lwoffii, Acinetobacter baumanii, Acinetobacter calcoaceticus, Alcaligenes latus, Alcaligenes faecalis, Flavobacterium aquatile, Moraxella saccharolytica, Neisseria elongate and Neisseria Lactamica. The incidence of Pseudomonas species was $33.3 \%$ and $53.3 \%$ in the examined samples of fresh and frozen Tilapia niloticus, $46.7 \%$ and 60.0 $\%$ in fresh and frozen Mugil cephalus, respectively, $33.3 \%$ and $40.0 \%$ in fresh and frozen shrimp, respectively table (4). The incidence of Aeromonas species were $46.7 \%$ and $33.3 \%$ in the examined samples of fresh and frozen Tilapia niloticus, 53.3 $\%$ and $40.0 \%$ in fresh and frozen Mugil cephalus, respectively, $33.3 \%$ and $40.0 \%$ in fresh and frozen shrimp respectively (table 6).

\section{DISCUSSION}

Aerobic plate count on fish s generally do not relate to food safety hazards, but sometimes can be useful to indicate quality, shelf life and post heat processing contamination. Fresh fish and fishery products often have an APC of $10^{6}-10^{8}$ without objectionable quality changes (Nickelson and Finne, 1992). The APC of the examined samples of each of fresh Tilapia niloticus, fresh Mugil cephalous, fresh shrimp, frozen Tilapia niloticus, frozen Mugil cephalous and frozen shrimp recorded in table (1) were $1.52 \times 10^{6} \pm 0.47 \times 10^{6}$, 
Table (1): Analytical results of (APC) /g of the examined fish samples ( $\mathrm{n}=15)$.

\begin{tabular}{cccc}
\hline Fish status & Min. & Max. & Mean \pm S.E* \\
\hline A. Fresh fish: & & & \\
Tilapia niloticus & $2.8 \times 10^{3}$ & $9.6 \times 10^{6}$ & $1.52 \times 10^{6} \pm 0.47 \times 10^{6}$ \\
Mugil cephalus & $4.7 \times 10^{3}$ & $8.5 \times 10^{6}$ & $7.14 \times 10^{5} \pm 1.84 \times 10^{5}$ \\
shrimp & $5.2 \times 0^{2}$ & $8.7 \times 10^{5}$ & $7.81 \times 10^{4} \pm 2.07 \times 10^{4}$ \\
A. Frozen fish: & & & \\
Tilapia niloticus & $3.7 \times 10^{3}$ & $7.6 \times 10^{6}$ & $3.08 \times 10^{5} \pm 1.31 \times 10^{5}$ \\
Mugil cephalus & $1.9 \times 10^{3}$ & $4.8 \times 10^{6}$ & $2.59 \times 10^{5} \pm 0.62 \times 10^{5}$ \\
shrimp & $1.3 \times 10^{2}$ & $9.6 \times 10^{5}$ & $1.36 \times 10^{4} \pm 0.42 \times 10^{4}$ \\
\hline \multicolumn{4}{c}{ S.E* $=$ Standard error }
\end{tabular}

Table (2): Analytical results of psychrotrophic count/g of the examined fish samples $(n=15)$.

\begin{tabular}{cccc}
\hline Fish status & Min. & Max. & Mean \pm S.E* \\
\hline A. Fresh fish: & & & \\
Tilapia niloticus & $4.9 \times 10^{3}$ & $3.5 \times 10^{6}$ & $2.67 \times 10^{5} \pm 0.45 \times 10^{5}$ \\
$\begin{array}{c}\text { Mugil cephalus } \\
\text { shrimp }\end{array}$ & $1.5 \times 10^{3}$ & $7.9 \times 10^{5}$ & $4.91 \times 10^{4} \pm 0.93 \times 10^{5}$ \\
A. Frozen fish: & $1.3 \times 10^{2}$ & $1.8 \times 10^{4}$ & $2.88 \times 10^{4} \pm 0.59 \times 10^{4}$ \\
Tilapia niloticus & $7.5 \times 10^{3}$ & $5.8 \times 10^{6}$ & $5.36 \times 10^{5} \pm 1.24 \times 10^{5}$ \\
$\begin{array}{c}\text { Mugil cephalus } \\
\text { shrimp }\end{array}$ & $3.7 \times 10^{3}$ & $1.9 \times 10^{6}$ & $1.72 \times 10^{5} \pm 0.46 \times 10^{5}$ \\
& $2.6 \times 0^{2}$ & $4.3 \times 10^{4}$ & $6.51 \times 10^{4} \pm 1.80 \times 10^{4}$ \\
\hline \multicolumn{4}{c}{ S.E $^{*}=$ Standard error }
\end{tabular}

Table (3): Serotyping of psychrotrophes isolated from the examined samples of fresh and frozen fish

\begin{tabular}{|c|c|c|c|c|c|c|c|c|c|c|c|c|}
\hline \multirow{3}{*}{ Serotypes } & \multicolumn{6}{|c|}{ Fresh fish } & \multicolumn{6}{|c|}{ Frozen fish } \\
\hline & \multicolumn{2}{|c|}{ Tilapia } & \multicolumn{2}{|c|}{ Mugil cephalus } & \multicolumn{2}{|c|}{ Shrimp } & \multicolumn{2}{|c|}{ Tilapia } & \multicolumn{2}{|c|}{ Mugil cephalus } & \multicolumn{2}{|c|}{ Shrimp } \\
\hline & No & $\%$ & No & $\%$ & No & $\%$ & No & $\%$ & No & $\%$ & No & $\%$ \\
\hline Acinetobacter lwoffii & 12 & 80 & 11 & 73.3 & 7 & 46.6 & 14 & 93.3 & 10 & 66.6 & 10 & 66.6 \\
\hline Acinetobacter baumanii & 7 & 46.6 & 10 & 66.6 & - & - & - & - & 11 & 73.3 & 10 & 66.6 \\
\hline Acinetobacter calcoaceticus & 6 & 40 & 7 & 46.6 & 7 & 46.6 & 10 & 66.6 & 8 & 53.3 & 9 & 60 \\
\hline Alcaligenes latus & 12 & 80 & - & - & 8 & 53.3 & 13 & 86.6 & - & - & - & - \\
\hline Alcaligenes faecalis & 9 & 60 & 13 & 86.6 & 9 & 60 & 14 & 93.3 & 15 & 100 & 12 & 80 \\
\hline Flavobacterium aquatile & 7 & 46.6 & 6 & 40 & 6 & 40 & - & - & 7 & 46.6 & 6 & 40 \\
\hline Moraxella saccharolytica & 4 & 26.6 & 3 & 20 & 3 & 20 & 3 & 20 & 4 & 26.6 & - & - \\
\hline Neisseria elongata & - & - & - & - & - & - & 6 & 40 & - & - & - & - \\
\hline Neisseria Lactamica & 3 & 20 & - & - & - & - & - & - & - & - & 3 & 20 \\
\hline
\end{tabular}

$\%$ was calculated according to total number of samples (15)

Table (4): Incidence of pseudomonas species isolated from the examined samples of fresh and frozen fish $(n=15)$

\begin{tabular}{ccc}
\hline Samples & $\begin{array}{c}\text { No. of } \\
\text { +ve samples }\end{array}$ & $\begin{array}{c}\text { \% of } \\
\text { +ve samples }\end{array}$ \\
\hline Fresh Tilapia niloticus & 5 & 33.3 \\
Fresh Mugil cephalus & 7 & 46.7 \\
Fresh shrimp & 5 & 33.3 \\
Frozen Tilapia niloticus & 8 & 53.3 \\
Frozen Mugil cephalus & 9 & 60.0 \\
Frozen shrimp & 6 & 40.0 \\
\hline
\end{tabular}


Bacteriological Evaluation of Some Fresh and Frozen fish

Table (5): Serotyping of pseudomonas species isolated from the examined samples of fresh and frozen fish

\begin{tabular}{|c|c|c|c|c|c|c|c|c|c|c|c|c|}
\hline \multirow{3}{*}{ Serotypes } & \multicolumn{6}{|c|}{ Fresh fish } & \multicolumn{6}{|c|}{ Frozen fish } \\
\hline & \multicolumn{2}{|c|}{ Tilapia } & \multicolumn{2}{|c|}{$\begin{array}{l}\text { Mugil } \\
\text { cephalus }\end{array}$} & \multicolumn{2}{|c|}{ shrimp } & \multicolumn{2}{|c|}{ Tilapia } & \multicolumn{2}{|c|}{$\begin{array}{l}\text { Mugil } \\
\text { cephalus }\end{array}$} & \multicolumn{2}{|c|}{ Shrimp } \\
\hline & No & $\%$ & No & $\%$ & No & $\%$ & No & $\%$ & No & $\%$ & No & $\%$ \\
\hline $\begin{array}{l}\text { Pseudomonas } \\
\text { Aeruginosa }\end{array}$ & - & - & - & - & 5 & 33.3 & - & - & - & - & 4 & 26.6 \\
\hline Pseudomonas fluorescens & 5 & 33.3 & 7 & 46.6 & 5 & 33.3 & 8 & 53.3 & 9 & 60 & 6 & 40 \\
\hline Pseudomonas alcaligenes & 5 & 33.3 & 6 & 40 & - & - & 8 & 53.3 & 9 & 60 & 6 & 40 \\
\hline $\begin{array}{l}\text { Pseudomonas } \\
\text { putrefaciens }\end{array}$ & 3 & 20 & 7 & 46.6 & 5 & 33.3 & 6 & 40 & 9 & 60 & - & - \\
\hline Pseudomonas fragi & 3 & 20 & 3 & 20 & 4 & 26.6 & - & - & - & - & 3 & 20 \\
\hline Pseudomonas acidoverans & 2 & 13.3 & 3 & 20 & - & - & - & - & 5 & 33.3 & - & - \\
\hline Pseudomonas vesicularis & 2 & 13.3 & - & - & 3 & 20 & - & - & - & - & - & - \\
\hline Pseudomonas proteolytica & 1 & 6.66 & 4 & 26.6 & - & - & - & - & - & - & 5 & 33.3 \\
\hline $\begin{array}{l}\text { Pseudomonas } \\
\text { pseudoalcaligenes }\end{array}$ & - & - & 2 & 13.3 & 3 & 20 & - & - & - & - & 3 & 20 \\
\hline Pseudomonas cepacia & - & - & 1 & 6.66 & 2 & 13.3 & - & - & 2 & 13.3 & 2 & 13.3 \\
\hline Pseudomonas diminuta & - & - & - & - & 2 & 13.3 & 3 & 20 & 3 & 20 & - & - \\
\hline Pseudomonas putida & - & - & - & - & - & - & 3 & 20 & - & - & 2 & 13.3 \\
\hline
\end{tabular}

$\%$ was calculated according to total number of samples (15)

Table (6): Incidence of Aeromonas species isolated from the examined samples of fresh and frozen fish $(n=15)$

\begin{tabular}{ccc}
\hline samples & $\begin{array}{c}\text { No. of } \\
\text { +ve samples }\end{array}$ & $\begin{array}{c}\text { \% of } \\
\text { +ve samples }\end{array}$ \\
\hline Fresh Tilapia niloticus & 7 & 46.7 \\
Fresh Mugil cephalus & 8 & 53.3 \\
Fresh shrimp & 5 & 33.3 \\
Frozen Tilapia niloticus & 5 & 33.3 \\
Frozen Mugil cephalus & 6 & 40.0 \\
Frozen shrimp & 6 & 40.0 \\
\hline
\end{tabular}

Table (7): Serotyping of Aeromonas species isolated from the examined samples of fresh and frozen fish

\begin{tabular}{|c|c|c|c|c|c|c|c|c|c|c|c|c|}
\hline \multirow{3}{*}{ Serotypes } & \multicolumn{6}{|c|}{ Fresh fish } & \multicolumn{6}{|c|}{ Frozen fish } \\
\hline & \multicolumn{2}{|c|}{ Tilapia } & \multicolumn{2}{|c|}{$\begin{array}{l}\text { Mugil } \\
\text { cephalus }\end{array}$} & \multicolumn{2}{|c|}{ shrimp } & \multicolumn{2}{|c|}{ Tilapia } & \multicolumn{2}{|c|}{$\begin{array}{l}\text { Mugil } \\
\text { cephalus }\end{array}$} & \multicolumn{2}{|c|}{ shrimp } \\
\hline & No & $\%$ & No & $\%$ & No & $\%$ & No & $\%$ & No & $\%$ & No & $\%$ \\
\hline $\begin{array}{l}\text { Aeromonas } \\
\text { hydrophila }\end{array}$ & 7 & 46.6 & 8 & 53.3 & 5 & 33.3 & 5 & 33.3 & 6 & 40 & - & - \\
\hline Aeromonas punctate & 7 & 46.6 & 8 & 53.3 & 3 & 20 & 5 & 33.3 & 6 & 40 & 5 & 33.3 \\
\hline Aeromonas diversa & 6 & 40 & 6 & 40 & 4 & 26.6 & 4 & 26.6 & 5 & 33.3 & 6 & 40 \\
\hline Aeromonas veronii & 5 & 33.3 & 4 & 26.6 & - & - & - & - & 4 & 26.6 & 5 & 33.3 \\
\hline Aeromonas bestirum & 4 & 26.6 & - & - & - & - & - & - & 3 & 20 & - & - \\
\hline $\begin{array}{l}\text { Aeromonas } \\
\text { fluvialis }\end{array}$ & - & - & - & - & 3 & 20 & - & - & 3 & 20 & 4 & 26.6 \\
\hline
\end{tabular}


$7.14 \times 10^{5} \pm 1.84 \times 10^{5}, \quad 7.81 \times 10^{4} \pm 2.07 \times 10^{4}$, $3.08 \times 10^{5} \pm 1.31 \times 10^{5}, 2.59 \times 10^{5} \pm 0.62 \times 10^{5}$ and $1.36 \times 10^{4} \pm 0.42 \times 10^{4}$ respectively. Higher counts of APC values were obtained by (Hytham, 2005) who found that the mean values for sardine $\left(3.95 \times 10^{6}\right)$, mullus spp $\left(3.67 \times 10^{6}\right)$, pargus spp. $\left(3.82 \times 10^{6}\right)$ and for chrysophyres $\left(2.16 \times 10^{6}\right)$. Lower results of APC values were obtained by (Shetty and Setty, 1990) who studied the bacteriological status of indian oil sardine stored in chilled sea water and found that the intial total plate count of fresh fish was $3.6 \times 10^{3} / \mathrm{g}$ which increased to $8.1 \times 10^{3} / \mathrm{g}$ during storage in chilled sea water $\left(2 \pm 1^{\circ} \mathrm{C}\right)$.

The psychrotrophic bacteria have received an increased attention by several investigators during recent years because fish held for long period at low temperature which greatly slow the multiplication of bacteria, but not stop their growth. Therefore, the favorable conditions for growth of psychrotrophic occurred. A rapid continuous gradual increase in psychrotrophic bacteria during storage of frozen fish can be occured (Al- Habib and Al- Aswad, 1986). The results of psychrotrophic count $(\mathrm{cfu} / \mathrm{g}$ ) of the examined samples of each of fresh Tilapia niloticus, fresh Mugil cephalous, fresh shrimp, frozen Tilapia niloticus, frozen Mugil cephalous and frozen shrimp recorded in table (2) were $2.67 \times 10^{5} \pm 0.45 \times 10^{5}, \quad 6.51 \times 10^{4} \pm 1.80 \times 10^{4}$, $2.88 \times 10^{4} \pm 0.59 \times 10^{4}, \quad 5.36 \times 10^{5} \pm 1.24 \times 10^{5}$, $1.72 \times 10^{5} \pm 0.46 \times 10^{5}$ and $4.91 \times 10^{4} \pm 0.93 \times 10^{5}$ respectively. These results came in accordance with those reported by (Elshafey, 2014) who found that the mean values for Saurus $\left(4.08 \times 10^{5} \pm\right.$ $\left.0.71 \times 10^{5}\right)$, mackerel $\left(9.95 \times 10^{4} \pm 2.13 \times 10^{4}\right)$ and horse mackerel $\left(3.66 \times 10^{4} \pm 0.749 \times 10^{4}\right)$. Lower results of total psychrotrophic count $(\mathrm{cfu} / \mathrm{g})$ were obtained by (Shereen et al., 2013) who examined 100 samples of Tilapia nilotica collected from different markets in Dakahlia governorate and revealed that the total psychrotrophic count was 3.1 $\mathrm{x} 10^{2} \pm 1.8 \times 10^{2}(\mathrm{cfu} / \mathrm{g})$. Alcaligenes faecalis was isolated with high incidence followed by Acinetobacter lwoffii, Acinetobacter baumanii, Acinetobacter calcoaceticus and Flavobacterium aquatile were the most psychrotrophic bacteria contaminate the examined samples as shown in table (3).

The incidence of Pseudomonas species isolated were $33.3 \%, 46.7 \%, 33.3 \%, 53.3 \%, 60 \%$, and $40 \%$ for fresh tilapia, fresh Mugil cephalus, fresh shrimp, frozen Tilapia, frozen Mugil cephalus, and frozen shrimp, respectively( table 4). Higher results were obtained by (Yagoub, 2009) who examined 150 fish samples and isolated Pseudomonas species from $62 \%$ of such samples and (Elshafey, 2014) isolate Pseudomonas species from frozen Saurus 23(76.67), mackerel 20(66.67) and horse mackerel 19(63.33). While, lower results were reported by (Rahmou- Abeer, 2002) isolated Pseudomonas species (28\%) from the examined samples and (Abou EL- Atta, 2003) isolated Pseudomonas species $26.05 \%$. The most Pseudomonas species contaminated these examined samples was Ps. alcaligenes and Ps. fluorescens followed by Ps. Putrefaciens as shown in table (5). The incidence of Aeromonas species were $46.7 \%$ and $33.3 \%$ in the examined samples of fresh and frozen Tilapia niloticus, 53.3 \% and $40.0 \%$ in fresh and frozen Mugil cephalus, respectively, $33.3 \%$ and $40.0 \%$ in fresh and frozen shrimp respectively table (6). These results agreed with those reported by (Abou El- Gheit et al., 1995) recorded that the incidence of Aeromonas species in Tilapia niloticus was $63.64 \%$. lower results by (Wong et al., 1994 a) isolated Aeromonas species from $10 \%$ of the examined samples of frozen fish, (Henin, 1995) declared the presence of Aeromonas species in incidence in imported frozen fish $(15.2 \%)$ than fresh water fish $(9.7 \%)$. Fresh cat fish show higher percentages of Aeromonas organism (11.6\%)

Higher results recorded by (Hafez et al., 1997) that the incidence of motile Aeromonas septicemia in Tilapia species was $75 \%$. The most Aeromonas species contaminated these examined samples was A. hydophila followed by A.diversa followed by $A$. punctata as shown in table (7).

\section{REFERENCES}

A.P.H.A. 1992. (American Public Health Association) Compendium of Methods for the Microbiological Examination of Foods 3rd Ed Washington, D.C, USA.

Abou EL- Atta, M.E.-S.L. 2003. Efficiency of polymerase chain reaction "PCR" in diagnosis of some Bacterial fish Pat,. Suez Canal University.

Abou El- Gheit, E.N., Moustafa, M., Sileim, T.A. 1995. Effect of sewage on bacterial infections among Tilapia fish. J. Egypt. Vet. Med. Ass. 55: 829-841.

Al- Habib, F.M.K., Al- Aswad, M.B. 1986. Some bacteriological changes in som frozen Iraqi fish. Iraqi. J. of Agricultural sciencs "Zonco 4: 103-110.

Baron, E.J., Finegold, S.M. 1990. Diagnostic Microbiology. The C. V. Masby co., 18130 Westline industrial Drive, St. Louis, Missouri 63146, USA.

Berrang, M.E., Brachett, R.E., Beuchat, L.R. 1989. Growth of listeria monocytogenes on fresh 
vegetables stored under acontrolled atmosphere. J. Food port 62: 702-705.

Collins, C., Lyne, P. 1984. Microbiological methods. 5th Ed. Microbiologically laboratory. British library, Butter Worth, UK. .

Dhanaraj, M., Haniffa, M., Muthu, R., Arockiaraj, A., Raman, S., Singh, A. 2008. Hematological analysis of common carp (Cyprimis carpio), Goldfish (Caras sins auratus ,(Tilapia (Oreochromis mossambicus) and Stinging Catfish (Heteropneustes fossilis) spontaneously infected with Aeromonas hydrophila. . Malaysian J. Science 27: 61-67.

Ebanks, R., Goguen, M., Mckhmon, S., Pinto, D., Ross, N. 2005. Identification of the major outer membrane protein of hydrophila J. Dis. Aqua, org 68: 29-38.

Elshafey, W.S. 2014. Psychrotrophs in frozen fish. M.V.Sc.thesis Vet. Med, Banha University.

FAO. 1992. Manual of food quality control. 4Rev.1.Microbiological analysis (Andrews, W. Ed (FAO food and nutrition. paper No.14/4 Rev.1.

Gram, L. 1993. Inhibitory effect against pathogenic and spoilage bacteria of Pseudomonas strains isolated from spoiled and fresh fish. . J. Appl. Environ. Microbiol. 59: 2197- 2203.

Gram, L., Huss, H.H. 199 .6Microbiological spoilage of fish and fish products. J International J. of Food Microbiol, 33: 121137.

Hafez, M.H., Abd EL Galyl, Y., Thoria, I.E. 1997. Survey on the pathological lesions of some septicaemic diseases in naturally infected Tilapia species in Sharkia Province. Benha Vet. Med. J. 8:164-168.

Henin, A.Y. 1995. Studies on motile Aeromonas species in frozen imported fish. Beni-Suef Vet. Med. Res, 295.

Hytham, M.A. 2005. Bacteriological evaluation of some salt water fish. M. V. Sc.thesis Vet. Med. Alexanderia University.

ICMSF. 1996. International commission of Microbiological Specification for Foods Microorganisms in Food. I. Their Significance and methods of enumeration. 3rd Ed. Univ. of Toronto, Canada.

Jay, J.M. 2000. Food preservation with modified atmospheres. 283:205. I.N.D.R. Hoidnian led. Modern Food Microbiology. Aspen publishers, Inc., Gaithcrsbura. Med.

Krieg, N., Holt, J. 1984. Bergeys Manual of systematic Bacteriology.Vol.1, Williams and Wilkins Co, Baltimore, USA.

Lu, Y ,.Bi, Z. 2007. Potential use of a transposon in 916 - generated mutant of Aeromonas hydrophila J- 1 defective in some exoproducts as a live attenuated vaccine. Prev. Vet. Med. 78: 779-784.

Nickelson, R., Finne, G. 1992. Fish, crustaceans and pre-cooked seafoods.ch. 47.in compendium of methodes for the microbiological examination of foods,. 3rd Ed, c. vandezant and D.F. spilttstoesser (Ed), p.875-895.American public Health Association, Washington,DC.

Quinn, P., Markey, B., Carter, M., Donelly, W., Leonard, F. 2002. Veterinary Microbiology and Microbial disease. . J. Black Well Science.

Rahmou- Abeer, A.A. 2002. Microbiological status of fish fillets marketed in Gharbia supermarket M. V. Sc. Thesis,. Faculty of Vet. Med, Moshtohor, Zagazig Univ. Benha branch.

Russell, S.M., 1998. Capacitance microbiology as a means of determining the quantity of spoilage bacteria on fish fillets. J. Food Prot. 61: 844-849.

Shereen, S., El-Dosoky, H., Hassan, A. 2013. Study the prevalence of psychotropic food borne bacteria in Tilapia nilation in Dakalliamanfets and its effect on fish quality. . Assuit Vet. Med. J. 59: 81 -89.

Shetty, T.S ,.Setty, T.M.R. 1990. Bacteriology of Indian Oil sardine (Sardinella longiceps Valenciennes) stored in chilled sea water. J. Fishery Technology 27: 141-144.

Wong, H.C., Chen, L.L., Yu, C.M. 1994 a. Occurrence of Vibrio in frozen sea foods and survival of Psychrotrophic Vibrio cholerae in broth and shrimp homogenate at low temperatures. Journal of food protection, 58: 262-267.

Yagoub, S.O. 2009. Isolation of Enterobacteriaceae and Pseudomonas spp. From raw fish sold in fish market in Khartoum state. J. Bacteriology Research, 1: 85-88. 